\title{
POTENSI PENERIMAAN PAJAK BUMI DAN BANGUNAN DI KOTA BENGKULU
}

\author{
Karona Cahya Susena \\ Fakultas Ekonomi Universitas Dehasen Bengkulu
}

\begin{abstract}
ABSTRAK
Karona Cahya Susena; Tujuan penelitian ini adalah untuk mengetahui proyeksi potensi penerimaan Pajak Bumi dan Bangunan (PBB) di Kota Bengkulu tahun 2014-2016. Jenis penelitian yang digunakan dalam penelitian ini adalah kuantitatif. Manfaat penelitian ini adalah sebagai bahan informasi kepada Pemerintah Daerah Kota Bengkulu dalam pengambilan kebijakan serta pengelolaan Pajak Bumi dan Bangunan (PBB) pada tahun 2014 sampai dengan 2016. Penelitian ini memberikan gambaran bahwa proyeksi potensi penerimaan Pajak Bumi dan Bangunan (PBB) di Kota Bengkulu mengalami peningkatan dari tahun 2014 hingga 2016. Besarnya potensi penerimaan Pajak Bumi dan Bangunan (PBB) di Kota Bengkulu Tahun 20142016 berturut-turut sebagai berikut: Tahun 2014 sebesar Rp12.285.612.144, Tahun 2015 sebesar Rp12.852.211.071, Tahun 2016 sebesar Rp.13.418.809.999, Peningkatan potensi penerimaan Pajak Bumi dan Bangunan (PBB) ini akan mendorong meningkatnya realisasi penerimaan PBB bagi Kota Bengkulu pada tiga tahun mendatang.
\end{abstract}

\section{ABSTRACT}

Karona Cahya Susena; The purpose of this study was to determine the potential revenue projections Land and Building Tax (PBB) in the city of Bengkulu years 2014-2016. This type of research used in this research is quantitative. The benefits of this research are as information material to the Regional Government of Bengkulu in policy making and management of land and building tax (PBB) in 2014 up to 2016. This study suggests that projected revenue potential land and building tax (PBB) in the city of Bengkulu experience increase from 2014 to 2016. The amount of potential revenue Land and Building Tax (PBB) in the city of Bengkulu year in a row from 2014 to 2016 as follows: 2014 by Rp12.285.612.144, 2015 by Rp12.852.211.071, 2016 by Rp.13.418.809.999, increased revenue potential land and building tax (PBB) will lead to greater realization of the UN acceptance for the city of Bengkulu in the next three years.

Key words: Land and Building Tax

\section{PENDAHULUAN}

Kota Bengkulu merupakan salah satu daerah berkembang di Indonesia. Melihat fenomena perkembangan daerah ini tidak terlepas dengan Pendapatan Asli Daerah. Pendapatan Asli Daerah (Nurcholis, 2007: 182) bahwa pendapatan yang diperoleh dari berbagai penerimaan daerah yang meliputi penerimaan pajak daerah, restribusi daerah, laba perusahaan daerah, dan lain-lain.

Pajak bagi pemerintah daerah berperan sebagai sumber pendapatan (budgetary function) yang utama dan juga sebagai alat pengatur (regulatory function). Pajak sebagai salah satu sumber pendapatan daerah digunakan untuk membiayai pengeluaran-pengeluaran pemerintah. Melihat pentingnya pajak bagi suatu daerah, terutama dalam menyokong pembangunan daerah itu sendiri dan merupakan pendapatan yang sangat potensial karena besarnya penerimaan pajak akan meningkat seiring laju pertumbuhan penduduk, perekonomian dan stabilitas politik.

Pemerintah Daerah memberlakukan beberapa jenis pungutan di Indonesia yang terdiri dari pajak pusat, pajak daerah, retribusi daerah, bea dan cukai, dan penerimaan negara bukan 
pajak. Salah satu pos penerimaan asli daerah dalam anggaran pendapatan belanja daerah adalah pajak daerah. Pajak daerah merupakan jenis pajak yang dipungut oleh Pemerintah Daerah dan digunakan untuk membiayai rumah tangga daerahnya.

Menurut Undang-undang No. 28 tahun 2009 tentang Pajak Daerah dan Restribusi Daerah, Pajak Daerah yang selanjutnya disebut adalah kontribusi wajib kepada Daerah yang terutang oleh orang pribadi atau badan yang bersifat memaksa berdasarkan Undang-Undang, dengan tidak mendapatkan imbalan secara langsung dan digunakan untuk keperluan Daerah bagi sebesar-besarnya kemakmuran rakyat.

Pemungutan pajak daerah oleh pemerintah daerah propinsi maupun kabupaten/ kota diatur oleh Undang-Undang nomor 28 Tahun 2009. Penerbitan UU tersebut merupakan langkah yang sangat strategis untuk lebih memantapkan kebijakan desentralisasi fiskal, khususnya dalam rangka membangun hubungan keuangan antara Pemerintah Pusat dan Daerah yang lebih ideal. Dari tahun ketahun, PAD Kota Bengkulu melalui pajak daerah belum mengalami perkembangan yang berarti. Padahal pajak merupakan salah satu komponen yang seharusnya menjadi kontributor penting bagi PAD. Hal ini selaras dengan Undang-Undang Nomor 28 Tahun 2009 tentang Pajak Daerah dan Retribusi Daerah (UU PDRD).

Pajak PBB merupakan pajak yang akan di kelola oleh DPPKA mulai pada tahun 2014. Dalam Peraturan Daerah No 05 tahun 2013 tentang pajak bumi dan bangunan perdesaan dan perkotaan. Yang menjadi Dasar Pengenaan PBB adalah Nilai Jual Objek Pajak (NJOP). Besarnya Nilai Jual Objek Pajak ditetapkan setiap tiga tahun oleh Menteri Keuangan, kecuali untuk daerah tertentu ditetapkan setiap tahun sesuai dengan perkembangan daerahnya

Data bagi hasil yang diterima Kota Bengkulu selama tahun 2009-2013 berdasar hasil target dan tealisasi yang ada dapat di lihat pada tabel 1. dibawah ini:

Tabel 1. Perbandingan Realisasi dan Target Pajak PBB data Hasil Bagi Kota Bengkulu Tahun 2009-2013

\begin{tabular}{|c|c|c|c|c|c|}
\hline No & Tahun & Target PBB (Rp) & Realisasi PBB (Rp) & $\%$ & Keterangan \\
\hline 1 & 2009 & $16.743 .624 .706,00$ & $13.000 .842 .971,00$ & 77,65 & Under Target \\
\hline 2 & 2010 & $12.552 .620 .397,20$ & $16.128 .489 .120,00$ & 128,49 & Over Target \\
\hline 3 & 2011 & $19.146 .989 .793,34$ & $19.568 .746 .582,00$ & 102,20 & Over Target \\
\hline 4 & 2012 & $18.710 .549 .582,00$ & $18.017 .292 .688,00$ & 96,29 & Under Target \\
\hline 5 & 2013 & $19.689 .990 .000,00$ & $16.778 .098 .917,00$ & 85,21 & Under Target \\
\hline
\end{tabular}

Sumber: DPPKA Kota Bengkulu, 2014

Dari data Perbandingan Realisasi dan Target Pajak PBB data Hasil Bagi Kota Bengkulu Tahun 2009-2013. Data tahun 2009 - 2013 merupakan data yang belum di lakukan perbaikan dimana masih banyak perbaikan data seperti fasilitas umum yang masih terdata yang seharusnya tidak menjadi objek pajak.

Peningkatan Pendapatan Asli Daerah (PAD) sangat tergantung dengan menggali potensi sumber-sumber pendapatan asli daerah. Oleh karena itu, ekstensifikasi dan intensifikasi sumber-sumber objek PAD menjadi sangat penting dalam upaya peningkatan pendapatan asli daerah.

Dalam rangka penyusunan APBD, DPPKA Kota Bengkulu harus menghitung potensi sumber-sumber pendapatan pajak daerah. Salah satu sumber pendapatan daerah adalah pajak bumi dan bangunan. Berdasarkan data tabel 1. Perlu di lakukan kajian untuk mengetahui proyeksi pendapatan pajak daerah khususnya pajak bumi dan bangunan untuk 3 (tiga) tahun kedepan yaitu tahun 2014, 2015 dan 2016.

\section{Landasan Teori Pajak}

Pajak menurut Undang-Undang Nomor 16 Tahun 2009, Pasal 1 ayat (1) Pajak adalah kontribusi wajib kepada Negara yang terutang oleh orang pribadi ataubadan yang bersifat 
memaksa berdasarkan Undang-Undang dengan tidak mendapatkan imbalan secara langsung dan digunakan untuk keperluan Negara bagisebesar-besarnya kemakmuran rakyat.

Menurut Prof. Dr. Rochmat Sumitro, SH (Mardiasmo, 2013:1) bahwa pajak merupakan iuran rakyat pada kas negara berdasarkan Undang-Undang (yang dapat di paksakan) dengan tiada mendapat jasa timbal (kontraprestasi) yang langsung dapat di tunjukkan dan yang di gunakan untuk membayar pengeluaran umum. Pajak menurut S. I. Djajadinigrat (Siti Resmi, 2014: 1) adalah sebagai suatu kewajiban menyerahkan sebagian dari kekayaan ke kas Negarayang disebabkan suatu keadaan, kejadian, dan perbuatan yang memberikan kedudukan tertentu, tetapi bukan sebagai hukuman, menurut peraturan yangditetapkan Pemerintah serta dapat dipaksakan tetapi tidak ada jasa timbal balik dari Negara secara langsung, untuk memelihara kesejahteraan secara umum. Pendapat lain tentang pengertian pajak di kemukakan oleh Dr. N. J. Fedelmann (Resmi, 2014: 2) menyatakan prestasi yang dipaksakan sepihak oleh dan terutang kepada penguasa (menurut norma-norma yang ditetapkannya secara umum), tanpa adanya kontraprestasi, dan semata-mata digunakan untuk menutup pengeluaran-pengeluaran umum. Dari pengerian di atas ciri-ciri yang melekat pada pengertian pajak adalah sebagai berikut:

1. Pajak di pungut berdasarkan Undang-Undang

2. Jasa timbal tidak di tunjukkan secara langsung

3. Pajak dipungut oleh pemerintah,baik pemerintah pusat maupun pemerintah daerah.

4. Diperuntukkan bagi pengeluaran - pengeluaran pemerintah (jika surplus digunakan untuk public saving)

\section{Jenis Pajak}

Ada beberapa jenis pajak di indonesia (Resmi, 2014:7-8):

1. Menurut Golongan

a. Pajak Langsung

pajak yang harus dibayar sendiri oleh wajib pajak dan tidak dapat dilimpahkan atau dibebankan kepada pihak lain atau orang lain.

Cotohnya: Pajak Penghasilan (PPh), dll

b. Pajak tidak Langsung

pajak yang pada akhirnya dapat dibebankan atau dilimpahkan kepada orang lain atau pihak ketiga.

Cotohnya: Pajak Pertambahan Nilai (PPN), dll

2. Menurut Sifatnya dibedakan:

a. Pajak Subjektif Yaitu pajak yang pengenaannya memperhatikan keadaan pribadi Wajib Pajak atau perngenan pajak yang memperhatikan keadaan subjeknya.

Contohnya: Pajak Penghasilan (PPh), dll

b. Pajak Objektif Yaitu pajak yang pengenaannya memperhatikan objeknya baik berupa benda, keadaan, perbuatan atau peristiwa yang mengakibatkan keadaan pribadi Subjek Pajak (Wajib Pajak) maupun tempat tinggal.

Contohnya: Pajak Pertambahan Nilai (PPN), dll

3. Menurut Lembaga Pemungutnya

a. Pajak Negara, dimana pajak yang dipungut oleh pemerintah pusat dan digunakan untuk membiayai rumah tangga negara pada umumnya.

Contoh: PPh, PPN dan PPnBM

b. Pajak Daerah, merupakan pajak yang dipungut oleh Pemerintah Daerah baik daerah tingkat I (pajak provinsi) maupun daerah tingkat II (pajak kabupaten/kota) dan digunakan untuk membiayai rumah tangga daerah masing-masing.

Contohnya: Pajak Kendaraan Bermotor,Bea Balik Nama Kendaraan Bermotor, Pajak Bahan bakar Kendaraan Bermotor, Pajak Penerangan Jalan, Pajak Hiburan, Pajak Sarang Burung Walet, Pajak Air permukaan, Pajak Hotel, Pajak Reklame, Pajak Penerangan Jalan, Pajak Mineral Bukan Logam dan Batuan, Pajak Parkir, Pajak Air Permukaan, Pajak bumi dan Bangunan Pedesaan dan perkotaan, BPHTB. 


\section{Pajak Daerah}

Pajak Daerah menurut Pasal 1 Undang-undang Nomor 28 Tahun 2009 menyatakan kontribusi wajib kepada Daerah yang terutang oleh orang pribadi atau badan yang bersifat memaksa berdasarkan Undang-Undang, dengan tidak mendapatkan imbalan secara langsung dan digunakan untuk keperluan Daerah bagi sebesar-besarnya kemakmuran rakyat.

Dengan demikian pajak daerah adalah iuran wajib pajak kepada daerah untuk membiayai pembangunan daerah. Pajak Daerah ditetapkan dengan undang-undang yang pelaksanaannya untuk di daerah diatur lebih lanjut dengan peraturan daerah. Pemerintah daerah dilarang melakukan pungutan selain pajakyang telah ditetapkan undang-undang (Pasal 2 UndangUndang Nomor 28 Tahun 2009).

Pajak yang di kelola pemerintah daerah baik Provinsi

Tabel 1. Perbandingan Jenis Pajak yang Dikelola Pemerintah Daerah

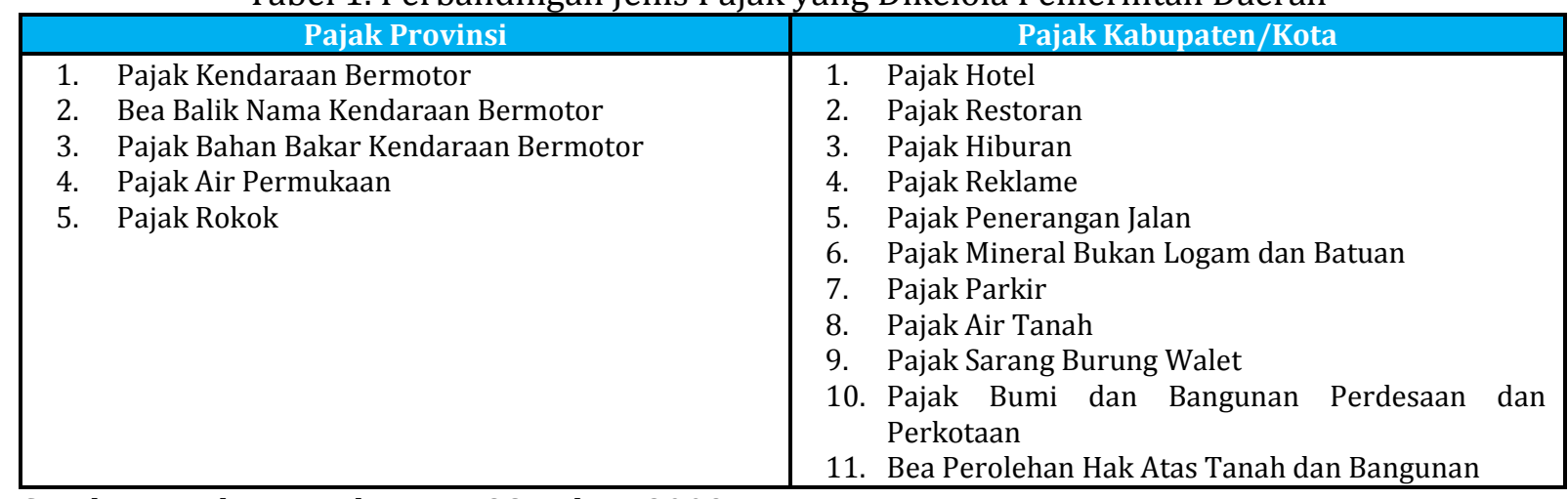

Sumber: Undang-Undang No 28 Tahun 2009

\section{Pajak yang Dikelola Provinsi}

Ada lima jenis pajak yang dikelola oleh provinsi yaitu Pajak Kendaraan Bermotor, Bea Balik Nama Kendaraan Bermotor, Pajak Bahan Bakar Kendaraan Bermotor, Pajak Air Permukaan dan Pajak Rokok.

1) Pajak Kendaraan Bermotor

Pajak Kendaraan Bermotor adalah pajak atas kepemilikan dan/atau penguasaan kendaraan bermotor. Kendaraan bermotor adalah semua kendaraan beroda beserta gandengannya yang digunakan di semua jenis jalan darat, dan digerakkan oleh peralatan teknik berupa motor atau peralatan lainnya yang berfungsi untuk mengubah suatu sumber daya energi tertentu menjadi tenaga gerak kendaraan bermotor yang bersangkutan, termasuk alat-alat berat dan alat-alat besar yang dalam operasinya menggunakan roda dan motor dan tidak melekat secara permanen serta kendaraan bermotor yang dioperasikan di air (Pasal 1 Undang-Undang Nomor 28 Tahun 2009).

Tarif Pajak Kendaraan Bermotor pribadi menurut Pasal 6 Undang-Undang Nomor 28 Tahun 2009 Tentang Pajak Daerah dan Retribusi Daerah ditetapkan sebagai berikut :

a. untuk kepemilikan kendaraan bermotor pertama paling rendah sebesar $1 \%$ (satu persen) dan paling tinggi sebesar $2 \%$ (dua persen);

b. untuk kepemilikan kendaraan bermotor kedua dan seterusnya tarif dapat ditetapkan secara progresif paling rendah sebesar $2 \%$ (dua persen) dan paling tinggi sebesar $10 \%$ (sepuluh persen).

Sedangkan tarif Pajak Kendaraan Bermotor angkutan umum, ambulans, pemadam kebakaran, sosial keagamaan, lembaga sosial dan keagamaan, Pemerintah/TNI/POLRI, Pemerintah Daerah, dan kendaraan lain yang ditetapkan dengan Peraturan Daerah, ditetapkan paling rendah sebesar 0,5\% (nol koma lima persen) dan paling tinggi sebesar 1\% (satu persen). Kemudian Tarif Pajak Kendaraan Bermotor alat-alat berat dan alat-alat 
besar ditetapkan paling rendah sebesar $0,1 \%$ (nol koma satu persen) dan paling tinggi sebesar 0,2\% (nol koma dua persen).

2) Bea Balik Nama Kendaraan Bermotor

Bea Balik Nama Kendaraan Bermotor adalah pajak atas penyerahan hak milik kendaraan bermotor sebagai akibat perjanjian dua pihak atau perbuatan sepihak atau keadaan yang terjadi karena jual beli, tukar menukar, hibah, warisan, atau pemasukan ke dalam badan usaha (Pasal 1 Undang-Undang Nomor 28 Tahun 2009).

Menurut Pasal 12 Undang-Undang Nomor 28 Tahun 2009 Tentang Pajak Daerah dan Retribusi Daerah tarif Bea Balik Nama Kendaraan Bermotor ditetapkan paling tinggi masing-masing sebagai berikut:

a. penyerahan pertama sebesar $20 \%$ (dua puluh persen) dan

b. penyerahan kedua dan seterusnya sebesar $1 \%$ (satu persen).

Khusus untuk kendaraan bermotor alat-alat berat dan alat-alat besar yang tidak menggunakan jalan umum tarif pajak ditetapkan paling tinggi masing-masing sebagai berikut :

a. penyerahan pertama sebesar $0,75 \%$ (nol koma tujuh puluh lima persen); dan

b. penyerahan kedua dan seterusnya sebesar 0,075\% (nol koma nol tujuh puluh lima persen).

3) Pajak Bahan Bakar Kendaraan Bermotor

Pajak Bahan Bakar Kendaraan Bermotor adalah pajak atas penggunaan bahan bakar kendaraan bermotor. Bahan bakar kendaraan bermotor adalah semua jenis bahan bakar cair atau gas yang digunakan untuk kendaraan bermotor (Pasal 1 Undang-Undang Nomor 28 Tahun 2009). Tarif Pajak Bahan Bakar Kendaraan Bermotor ditetapkan paling tinggi sebesar 10\% (sepuluh persen). Khusus tarif Pajak Bahan Bakar Kendaraan Bermotor untuk bahan bakar kendaraan umum dapat ditetapkan paling sedikit 50\% (lima puluh persen) lebih rendah dari tarif Pajak Bahan Bakar Kendaraan Bermotor untuk kendaraan pribadi (Pasal 19 Undang-Undang Nomor 28 Tahun 2009).

4) Pajak Air Permukaan

Menurut Undang-Undang Nomor 28 Tahun 2009 Tentang Pajak Daerah dan Retribusi Daerah, Pajak Air Permukaan adalah pajak atas pengambilan dan/atau pemanfaatan air permukaan. Air permukaan adalah semua air yang terdapat pada permukaan tanah, tidak termasuk air laut, baik yang berada di laut maupun di darat. Tarif Pajak Air Permukaan ditetapkan paling tinggi sebesar 10\% (Pasal 24 Undang-Undang nomor 28 Tahun 2009).

5) Pajak Rokok

Menurut Undang-Undang Nomor 28 Tahun 2009 Tentang Pajak Daerah dan Retribusi Daerah, Pajak Rokok adalah pungutan atas cukai rokok yang dipungut oleh Pemerintah. Tarif Pajak Rokok ditetapkan sebesar 10\% (sepuluh persen) dari cukai rokok. Pajak Rokok dikenakan atas cukai rokok yang ditetapkan oleh Pemerintah (Pasal 29 Undang-Undang Nomor 28 Tahun 2009).

Penerimaan pajak rokok, baik bagian Provinsi maupun bagian Kabupaten/kota, dialokasikan paling sedikit $50 \%$ untuk mendanai pelayanan kesehatan masyarakat dan penegakan hukum oleh aparat yang berwenang ( Pasal 31 Undang-Undang Nomor 28 Tahun 2009).

\section{Pajak yang Dikelola Kabupaten/Kota}

Ada 11 jenis pajak yang dikelola oleh Kabupaten/Kota, pajak yang termasuk pajak yang dikelola Kabupaten/Kota menurut Undang-Undang Nomor 28 Tahun 2009 Tentang Pajak Daerah dan retribusi Daerah adalah sebagai berikut:

1) Pajak Hotel

Adalah pajak atas pelayanan yang disediakan oleh hotel. Hotel adalah fasilitas penyedia jasa penginapan/peristirahatan termasuk jasa terkait lainnya dengan dipungut bayaran, yang mencakup juga motel, losmen, gubuk pariwisata, wisma pariwisata, pesanggrahan, rumah penginapan dan sejenisnya, serta rumah kos dengan jumlah kamar lebih dari 10 
(sepuluh). Tarif Pajak Hotel ditetapkan paling tinggi sebesar 10\% (Pasal 35 UndangUndang Nomor 28 Tahun 2009).

2) Pajak Restoran

Adalah pajak atas pelayanan yang disediakan oleh restoran. Restoran adalah fasilitas penyedia makanan dan/atau minuman dengan dipungut bayaran, yang mencakup juga rumah makan, kafetaria, kantin, warung, bar, dan sejenisnya termasuk jasa boga/katering. Tarif Pajak Restoran ditetapkan paling tinggi sebesar 10\% (Pasal 40 Undang-Undang Nomor 28 Tahun 2009).

3) Pajak Hiburan

Adalah pajak atas penyelenggaraan hiburan. Hiburan adalah semua jenis tontonan, pertunjukan, permainan, dan/atau keramaian yang dinikmati dengan dipungut bayaran. Tarif Pajak Hiburan ditetapkan paling tinggi sebesar 35\% (tiga puluh lima persen). Khusus untuk hiburan berupa pagelaran busana, kontes kecantikan, diskotik, karaoke, klab malam, permainan ketangkasan, panti pijat, dan mandi uap/spa, tarif Pajak Hiburan dapat ditetapkan paling tinggi sebesar 75\% (tujuh puluh lima persen). Khusus hiburan kesenian rakyat/tradisional dikenakan tarif Pajak Hiburan ditetapkan paling tinggi sebesar 10\% (Pasal 45 Undang-Undang Nomor 28 Tahun 2009).

4) Pajak Reklame

Adalah pajak atas penyelenggaraan reklame. Reklame adalah benda, alat, perbuatan, atau media yang bentuk dan corak ragamnya dirancang untuk tujuan komersial memperkenalkan, menganjurkan, mempromosikan, atau untuk menarik perhatian umum terhadap barang, jasa, orang, atau badan, yang dapat dilihat, dibaca, didengar, dirasakan, dan/atau dinikmati oleh umum. Tarif Pajak Reklame ditetapkan paling tinggi sebesar 25\% (Pasal 50 Undang-Undang Nomor 28 Tahun 2009).

5) Pajak Penerangan Jalan

Adalah pajak atas penggunaan tenaga listrik, baik yang dihasilkan sendiri maupun diperoleh dari sumber lain. Tarif Pajak Penerangan Jalan ditetapkan paling tinggi sebesar $10 \%$ (sepuluh persen). Penggunaan tenaga listrik dari sumber lain oleh industri, pertambangan minyak bumi dan gas alam, tarif Pajak Penerangan Jalan ditetapkan paling tinggi sebesar 3\% (tiga persen). Penggunaan tenaga listrik yang dihasilkan sendiri, tarif Pajak Penerangan Jalan ditetapkan paling tinggi sebesar 1,5\% (Pasal 55 Undang-Undang Nomor 28 Tahun 2009).

6) Pajak Mineral Bukan Logam dan Batuan

Adalah pajak atas kegiatan pengambilan mineral bukan logam dan batuan, baik dari sumber alam di dalam dan/atau permukaan bumi untuk dimanfaatkan. Mineral Bukan Logam dan Batuan adalah mineral bukan logam dan batuan sebagaimana dimaksud di dalam peraturan perundang-undangan di bidang mineral dan batubara. Tarif Pajak Mineral Bukan Logam dan Batuan ditetapkan paling tinggi sebesar 25\% (Pasal 60 Undang-Undang Nomor 28 Tahun 2009).

7) Pajak Parkir

Adalah pajak atas penyelenggaraan tempat parkir di luar badan jalan, baik yang disediakan berkaitan dengan pokok usaha maupun yang disediakan sebagai suatu usaha, termasuk penyediaan tempat penitipan kendaraan bermotor.Parkir adalah keadaan tidak bergerak suatu kendaraan yang tidak bersifat sementara. Tarif Pajak Parkir ditetapkan paling tinggi sebesar 30\% (Pasal 65 Undang-Undang Nomor 28 Tahun 2009).

8) Pajak Air Tanah

Adalah pajak atas pengambilan dan/atau pemanfaatan air tanah. Air Tanah adalah air yang terdapat dalam lapisan tanah atau batuan di bawah permukaan tanah. Tarif Pajak Air Tanah ditetapkan paling tinggi sebesar 20\% (Pasal 70 Undang-Undang Nomor 28 Tahun 2009).

9) Pajak Sarang Burung Walet

Adalah pajak atas kegiatan pengambilan dan/atau pengusahaan sarang burung walet. Burung walet adalah satwa yang termasuk marga collocalia, yaitu collocalia fuchliap haga, collocalia maxina, collocalia esculanta,dan collocalia linchi. Tarif Pajak Sarang Burung 
Walet ditetapkan paling tinggi sebesar 10\% (Pasal 75 Undang-Undang Nomor 28 Tahun 2009).

10) Pajak Bumi dan Bangunan Perdesaan dan Perkotaan

Adalah pajak atas bumi dan/atau bangunan yang dimiliki, dikuasai, dan/atau dimanfaatkan oleh orang pribadi atau Badan, kecuali kawasan yang digunakan untuk kegiatan usaha perkebunan, perhutanan, dan pertambangan.

Bumi adalah permukaan bumi yang meliputi tanah dan perairan pedalaman serta laut wilayah kabupaten/kota. Bangunan adalah konstruksi teknik yang ditanam atau dilekatkan secara tetap pada tanah dan/atau perairan pedalaman dan/atau laut. Tarif Pajak Bumi dan Bangunan Perdesaan dan Perkotaan ditetapkan paling tinggi sebesar 0,3\% (Pasal 80 Undang-Undang Nomor 28 Tahun 2009).

11) Bea Perolehan Hak atas Tanah dan Bangunan

Adalah pajak atas perolehan hak atas tanah dan/atau bangunan. Perolehan Hak atas Tanah dan/atau Bangunan adalah perbuatan atau peristiwa hukum yang mengakibatkan diperolehnya hak atas tanah dan/atau bangunan oleh orang pribadi atau Badan. Tarif Bea Perolehan Hak atas Tanah dan Bangunan ditetapkan paling tinggi sebesar 5\% (Pasal 88 Undang-Undang Nomor 28 Tahun 2009).

\section{Pajak Bumi dan Bangunan}

Pajak Bumi dan Bangunan (PBB). PBB adalah pajak yang bersifat kebendaan dalam arti besarnya pajak terutang ditentukan oleh keadaan objek yaitu bumi dan atau bangunan. Keadaan subjek tidak ikut menentukan besarnya pajak. PBB pada awalnya merupakan pajak pusat yang alokasi penerimaannya dialokasikan ke daerah-daerah dengan proporsi tertentu, namun demikian dalam perkembangannya berdasarkan Undang-Undang No. 28 Tahun 2009 tentang PDRD pajak ini khususnya sektor perkotaan dan pedesaan menjadi sepenuhnya pajak daerah.

\section{Filosofi Pajak Bumi dan Bangunan}

Landasan Filosofi Pajak Bumi dan Bangunan (PBB) adalah sebagai berikut:

a. Bahwa pajak merupakan sumber penerimaan negara yang penting bagi pelaksanaan dan peningkatan pembangunan nasional untuk meningkatkan kemakmuran dan kesejahteraan rakyat, oleh sebab itu perlu peningkatan peran serta masyarakat,

b. Bahwa bumi dan bangunan memberikan keuntungan dan/atau kedudukan sosial ekonomi yang lebih baik bagi orang/badan yang mempunyai suatu hak atasnya atau memperoleh manfaat darinya, oleh sebab itu wajar apabila kepada mereka diwajibkan memberikan sebagian dari manfaat atau kenikmatan yang diperolehnya kepada negara melalui pajak.

\section{Pengertian dan Dasar hukum PBB}

PBB dikenakan terhadap objek pajak berupa tanah dan atau bangunan yang didasarkan pada azas kenikmatan dan manfaat, dan dibayar setiap tahun. PBB pengenaannya didasarkan pada Undang-undang No. 12 tahun 1985 tentang Pajak Bumi dan Bangunan sebagaimana telah diubah dengan Undang-undang No.12 tahun 1994. Namun demikian dalam perkembangannya PBB sektor pedesaan dan perkotaan menjadi pajak daerah yang diatur dalam UndangUndang No.28 Tahun 2009 tentang Pajak Daerah dan Retribusi Daerah (PDRD) Pasal 77 sampai dengan Pasal 84 mulai tahun 2010.

Dalam bab I diatur tentang Ketentuan Umum yang memberikan penjelasaan tentang istilahistilah teknis atau definisi-definisi PBB seperti pengertian :

a. Bumi adalah permukaan bumi dan tubuh bumi yang ada dibawahnya. Pengertian ini berarti bukan hanya tanah permukaan bumi saja tetapi betul-betul tubuh bumi dari permukaan sampai dengan magma, hasil tambang, gas material yang lainnya.

b. Bangunan adalah konstruksi teknik yang ditanam atau dilekatkan secara tetap pada tanah dan/atau perairan. 
Dalam pasal 77 ayat (2) Undang-Undang PDRD, disebutkan bahwa termasuk dalam pengertian bangunan adalah :
a. jalan lingkungan yang terletak dalam suatu kompleks bangunan seperti hotel, pabrik, dan emplasemennya dan lain-lain yang satu kesatuan dengan kompleks bangunan tersebut,
b. jalan TOL,
c. kolam renang,
d. pagar mewah,
e. tempat olah raga,
f. galangan kapal, dermaga,
g. taman mewah,
h. tempat penampungan/kilang minyak, air dan gas, pipa minyak,
i. fasilitas lain yang memberikan manfaat.

\section{Objek PBB}

Objek PBB adalah bumi dan/atau bangunan, dimana pengertian bumi dan/atau bangunan adalah sebagai berikut :

Bumi adalah permukaan bumi yang meliputi tanah dan perairan pedalaman serta laut wilayah Indonesia, dan tubuh bumi yang ada dibawahnya. Bangunan, adalah kontruksi teknik yang di tanam atau di lekatkan secara tetap pada tanah dan/atau perairan.

Tidak semua objek bumi dan bangunan akan dikenakan PBB, ada juga objek yang di kecualikan dari pengenaan PBB adalah apabila sebagai berikut :

a. digunakan semata-mata untuk melayani kepentingan umum di bidang ibadah, sosial, kesehatan, pendidikan dan kebudayaan nasional, yang tidak dimaksud-kan untuk memperoleh keuntungan,

b. digunakan untuk kuburan, peninggalan purbakala, atau yang sejenis dengan itu,

c. merupakan hutan lindung, hutan suaka alam, hutan wisata, taman nasional, tanah penggembalaan yang dikuasai oleh desa, dan tanah negara yang belum di bebani suatu hak,

d. digunakan oleh perwakilan diplomatik, konsulat berdasarkan asas perlakuan timbal balik,

e. digunakan oleh badan atau perwakilan organisasi internasional yang ditentukan oleh Menteri Keuangan.

Objek pajak yang digunakan oleh negara untuk penyelenggaraan pemerintahan, penentuan pengenaan pajaknya diatur lebih lanjut dengan Peraturan Pemerintah.

\section{Subjek PBB}

Subjek PBB adalah orang atau badan yang secara nyata mempunyai suatu hak atas bumi, dan/atau memperoleh manfaat atas bumi, dan/atau memiliki, menguasai, dan/atau memperoleh manfaat atas bangunan. Melihat pengertian subjek pajak tersebut, tidak jarang ada objek pajak yang diakui oleh lebih dari satu orang subjek pajak, yang berarti ada satu objek pajak tetapi memiliki beberapa wajib pajak. Apabila terjadi statu kejadian dimana satu objek pajak dimiliki/dikuasai oleh beberapa subjek pajak atau satu objek pajak belum diketahui dengan jelas siapa Wajib Pajaknya, maka hal pertama yang perlu dilakukan adalah melihat perjanjian (agreement) antara para pihak yang berkepentingan terhadap objek pajak tersebut. Dalam perjanjian tersebut salah satu pasalnya biasanya membahas siapa yang akan melakukan kewajiban pembayaran pajak termasuk pajak Bumi dan Bangunan. Apabila dalam perjanjian tidak disebutkan atau memang terjadi lebih dari satu yang memanfaatkan objek pajak sehingga belum diketahui siapa yang menjadi wajib pajak Direktorat Jenderal Pajak dapat menetapkan subjek pajaknya (UU No 12 tahun 1994 Pasal 4 ayat 3).

\section{Penilaian PBB}

Berbicara masalah PBB tidak akan terlepas dari nilai properti itu sendiri. Karena besarnya PBB yang akan dibayarkan oleh WP akan tergantung pada nilainya. Penilaian objek PBB pedesaan 
dan perkotaan meliputi penilaian objek tanah dan bangunan yang dilakukan oleh Ditjen Pajak (pemerintah daerah menurut UU No. 28 Tahun 2009) untuk menentukan NJOP yang akan dijadikan sebagai dasar pengenaan pajak.

Untuk menilai objek properti tersebut digunakan beberapa metode penilaian sebagai berikut:

1. Pendekatan Data Pasar (Market Data Approach).

a. NJOP dihitung dengan cara membandingkan Objek pajak yang sejenis dengan Objek lain yang telah diketahui harga pasarnya.

b. Pendekatan ini pada umumnya digunakan untuk menentukan NJOP tanah, namun dapat juga dipakai untuk menentukan NJOP bangunan.

2. Pendekatan Biaya (Cost Approach).

Pendekatan ini digunakan untuk menentukan nilai tanah atau bangunan terutama untuk menentukan NJOP bangunan dengan menghitung seluruh biaya yang dikeluarkan untuk membuat bangunan baru yang sejenis dikurangi dengan penyusutan phisiknya.

3. Pendekatan Pendapatan (Income Approach)

a. Pendekatan ini digunakan untuk menentukan NJOP yang tidak dapat dilakukan berdasarkan pendekatan data pasar atau pendekatan biaya, tetapi ditentukan berdasarkan hasil bersih objek pajak tersebut,

b. Pendekatan ini terutama digunakan untuk menentukan NJOP galian tambang atau objek perairan.

\section{Metode Penelitian}

Metode yang digunakan adalah analisis Trend, Metode ini menderet data secara tahunan kemudian memproyeksikan kecenderungannya di masa yang akan datang. Formula garis trend adalah sebagai berikut:

Keterangan:

$$
\mathbf{Y}=\mathbf{a}+\mathbf{b X}
$$

a : Konstanta

b : Koefisien Korelasi

Y : Nilai Perkiraan (Proyeksi)

$\mathrm{X} \quad$ : Periode Waktu

Data akan diolah dengan menggunakan softwares MS excel, dan ditampilkan dengan media tabulasi, grafik, dan chart. Selanjutnya dari informasi target dan realisasi pajak daerah yang bisa diperoleh data dari DPPKA Kota Bengkulu.

\section{HASIL DAN PEMBAHASAN}

Data realisasi PBB dari bagi hasil tersebut secara riil untuk Kota Bengkulu sebesar $60 \%$ di karenakan $40 \%$ adalah dana bagi hasil dari perkebunan, kehutanan dan lainnya. maka dapat dijadikan pedoman untuk perhitungan proyeksi pajak dapat di lihat pada tabel 2. Sebagai berikut:

Tabel 2. Realisasi PBB pada DPPKA Kota Bengkulu Tahun 2009-2013

\begin{tabular}{|c|c|r|r|r|r|}
\hline Tahun & $\mathbf{X}$ & $\begin{array}{c}\text { Realisasi Pajak } \\
\text { PBB (Rp) }\end{array}$ & \multicolumn{1}{|c|}{$\mathbf{X}^{2}$} & \multicolumn{1}{|c|}{$\mathbf{Y}^{2}$} & \multicolumn{1}{|c|}{ XY } \\
\hline 2009 & 0 & 7.800 .505 .783 & 0 & 60.847 .890 .464 .376 .000 .000 & - \\
\hline 2010 & 1 & 9.677 .093 .472 & 1 & 93.646 .138 .065 .825 .000 .000 & 9.677 .093 .472 \\
\hline 2011 & 2 & 11.741 .247 .949 & 4 & 137.856 .903 .404 .593 .000 .000 & 23.482 .495 .898 \\
\hline 2012 & 3 & 10.810 .375 .613 & 9 & 116.864 .220 .889 .821 .000 .000 & 32.431 .126 .838 \\
\hline 2013 & 4 & 10.066 .859 .350 & 16 & 101.341 .657 .176 .709 .000 .000 & 40.267 .437 .401 \\
\hline Jumlah & $\mathbf{1 0}$ & $\mathbf{5 0 . 0 9 6 . 0 8 2 . 1 6 6 , 8 0}$ & $\mathbf{3 0}$ & $\mathbf{5 1 0 . 5 5 6 . 8 1 0 . 0 0 1 . 3 2 4 . 0 0 0 . 0 0 0 , 0 0}$ & $\mathbf{1 0 5 . 8 5 8 . 1 5 3 . 6 1 0}$ \\
\hline
\end{tabular}

Sumber: DPPKA Kota Bengkulu, 2014 (diolah) 
Menggunakan perhitungan trend dengan metode last Square maka dapat di peroleh persamaan $Y=888.601 .8578,15+566.598 .927,60 X$. Dengan menggunakan persamaan tersebut dapat ditentukan proyeksi untuk tahun 2014 sampai dengan 2016, sebagai berikut:

Tabel 3. Proyeksi PBB pada DPPKA Kota Bengkulu Tahun 2014-2016

\begin{tabular}{|c|c|c|}
\hline No & Tahun & Proyeksi PBB (Rp) \\
\hline 1 & 2014 & 12.285 .612 .144 \\
\hline 2 & 2015 & 12.852 .211 .071 \\
\hline 3 & 2016 & 13.418 .809 .999 \\
\hline
\end{tabular}

Sumber: Data Diolah, 2014

Gambar 1. Trend Penerimaan PBB Pada DPPKA Kota Bengkulu Tahun 2014-2016

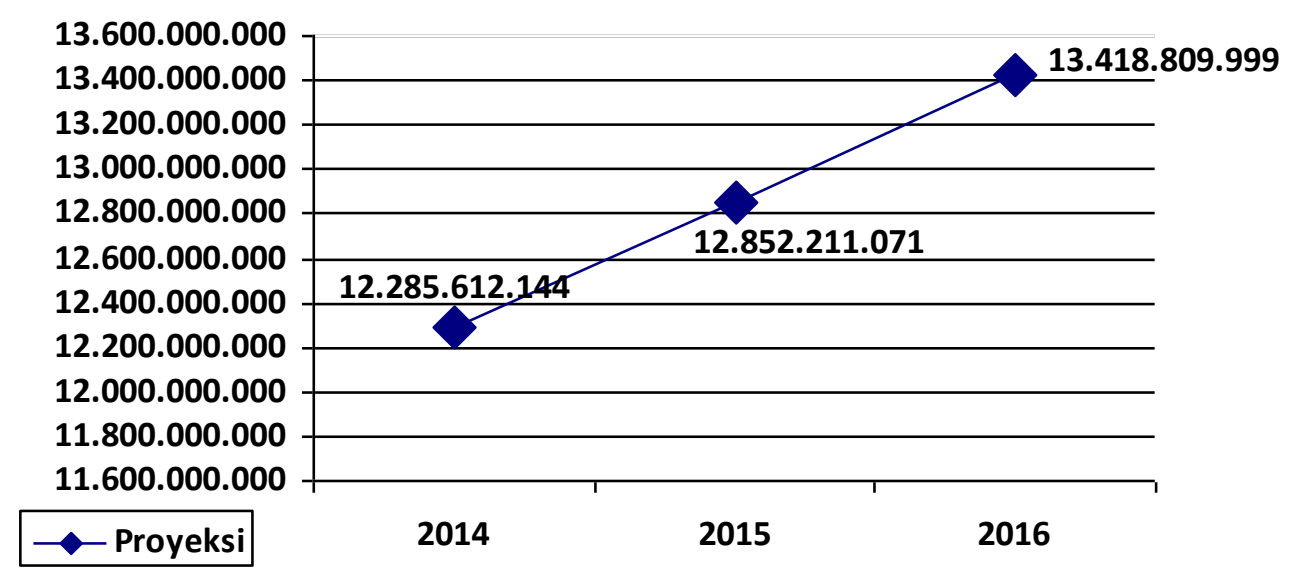

Tabel 3 dan gambar 1 menunjukkan bahwa Potensi penerimaan Pajak Bumi dan Bangunan (PBB) di Kota Bengkulu dari tahun ke tahun mengalami peningkatan. Hal ini disebabkan oleh perkembangan pembangunan, perekonomian masyarakat, serta dampak pariwisata baik secara langsung maupun tidak langsung. Peningkatan tersebut bisa di karenakan adanya penyesuaian Nilai Jual Objek Pajak (NJOP). Adanya pengaruh pembangunan, perekonomian, dan pariwisata mengakibatkan alih fungsi lahan dari tanah sawah/ persawahan menjadi tanah kering untuk permukiman/ perumahan, akomodasi pariwisata, seperti hotel, restoran, ruko, toko-toko, perkantoran, dan lain sebagainya sebagai penunjang atau pendukung pembangunan, perekonomian, dan pariwisata. Dengan beralih fungsinya lahan pertanian/tanah sawah menjadi tanah kering mengakibatkan nilai tanah berubah, di mana Nilai Jual Objek Pajak (NJOP) akan naik, sehingga secara otomatis PBB akan naik pula PBB yang selama ini merupakan pajak pusat dan daerah hanya menerima bagi hasil pajak dari pemerintah pusat, dengan diberlakukannya Undang-Undang Nomor 28 Tahun 2009 tentang Pajak Daerah dan Retribusi Daerah (PDRB) paling lambat Desember 2013, di mana PBB menjadi pajak daerah. Hal ini secara langsung akan meningkatkan penerimaan pajak dari PBB, karena seratus persen merupakan penerimaan daerah dan bukan bagi hasil pajak dari pemerintah pusat.

Sedangkan upaya yang harus dilaksanakan dalam meningkatkan PBB adalah dengan meningkatkan pokok ketetapan bumi dan bangunan NJOP, meningkatkan kualitas data yang akurat dan up to date, serta memiliki data base yang pasti. Selain itu juga dilaksanakan reklasifikasi NJOP dengan meriilkan NJOP khususnya tanah disesuaikan dengan peruntukannya. Besarnya potensi penerimaan PBB di Kota Bengkulu tahun 2014-2016 berturut-turut sebagai berikut tahun 2014 prediksi maksimum potensi penerimaan PBB sebesar Rp12.285.612.144 untuk tahun 2015 prediksi maksimum potensi penerimaan PBB sebesar Rp12.852.211.071 untuk tahun 2016 prediksi maksimum potensi penerimaan PBB sebesar Rp13.418.809.999 
untuk Peningkatan potensi penerimaan PBB ini akan mendorong meningkatnya realisasi penerimaan PBB bagi Kota Bengkulu pada tiga tahun mendatang

\section{Kesimpulan}

Berdasarkan hasil penelitian yang dilakukan, maka dapat ditarik kesimpulan Besarnya potensi penerimaan PBB di Kota Bengkulu tahun 2014-2016 berturut-turut dari tahun 2014 prediksi maksimum potensi penerimaan PBB sebesar Rp12.285.612.144. Pada tahun 2015 prediksi maksimum potensi penerimaan PBB sebesar Rp12.852.211.071. sedangkan tahun 2016 prediksi maksimum potensi penerimaan PBB sebesar Rp13.418.809.999.

\section{Saran}

Agar realisasi penerimaan pajak bumi dan bangunan nantinya dapat sesuai dengan apa yang telah di targetkan, pemerintah daerah harus memiliki komitmen untuk mengatasi berbagai kendala yang selama ini kerap ditemui dan menjadi persoalan dalam optimalisasi penerimaan Pajak Bumi dan Bangunan sebagai berikut:

1. Perbaikan kualitas data pajak daerah dan wajib pajak di Kota Bengkulu yang memberikan kepastian jumlah objek pajaknya. Pemerintah Kota Bengkulu perlu melakukan investarisasi untuk melakukan sensus usaha yang dapat dikenai pajak daerah melalui kerjasama dengan melibatkan aparat pemerintah kelurahan dalam pengelolaan pajak daerah, mengingat aparatur kelurahan sangat dekat dengan masyarakat. Sensus ini perlu dilakukan karena database yang dimiliki Pemerintah Kota Bengkulu tidak lengkap dan masih banyak usaha dari jenis objek pajak yang belum didata.

2. Pemerintah daerah diharapkan lebih sering memberikan penyuluhan mengenai pajak daerah kepada masyarakat, sistem pendekatan yang baik, manajemen yang teratur serta memberikan penghargaan kepada pembayar pajak, agar keinginan dan partisipasi masyarakat untuk membayar pajak dapat didorong oleh pemahaman mereka akan pentingnya pajak daerah.

3. Penegakan hukum (law enforcement) perlu dilakukan dengan tegas. Kasus penunggakan pajak, penghindaran pajak, dan penipuan pajak merupakan kasus kriminal yang harus diproses secara hukum. Pemerintah harus memberikan sanksi yang tegas sehingga dapat menimbulkan efek jera bagi para pembangkang pajak.

\section{DAFTAR PUSTAKA}

Hanif Nurcholis. 2007. Teori dan Praktik Pemerintahan dan Otonomi Daerah. Jakarta: PT Grasindo

Mardiasmo, 2013, Perpajakan. Edisi Revisi. Yogyakarta. Penerbit Andi

Peraturan Daerah Kota Bengkulu No 05 tahun 2013 Tentang Pajak Bumi Dan Bangunan Perdesaan Dan Perkotaan

Siti Resmi, 2014. Perpajakan Teori dan Kasus. Edisi 8 Buku 1, Jakarta, Salemba Empat

Undang-undang No. 12 tahun 1994 tentang Pajak Bumi dan Bangunan

Undang-undang No. 28 tahun 2009 tentang Pajak Daerah dan Restribusi Daerah 